\title{
Correction to: Training Intensity, Not Duration, May Be Key to Upregulating Presynaptic Proteins of Calcium Dynamics and Calcium-Dependent Exocytosis in Fast- and Slow-Twitch Skeletal Muscles, in Addition to Maintaining Performance After Detraining
}

\author{
Ali Gorzi ${ }^{1}$. Fatemeh Jafari ${ }^{1}$. Nasrin Allahmoradi ${ }^{1}$. Ahmad Rahmani ${ }^{1} \cdot$ Walter Krause Neto ${ }^{2}$ (i) \\ Published online: 29 December 2021 \\ (c) Springer Science+Business Media, LLC, part of Springer Nature 2021
}

Correction to: Molecular Neurobiology (2021) 58:6670-6683

https://doi.org/10.1007/s12035-021-02576-7

In the original manuscript, the authors missed to add Prof. Ali Gorzi as one of the corresponding author. With this, the authors requested this correction.

The orignal paper has been corrected.

Publisher's Note Springer Nature remains neutral with regard to jurisdictional claims in published maps and institutional affiliations.

The original article can be found online at https://doi.org/10.1007/ s12035-021-02576-7.

Ali Gorzi

ali_gorzi@znu.ac.ir

$\triangle$ Walter Krause Neto

wild_krause@hotmail.com

1 Department of Sport Sciences, University of Zanjan, Zanjan, Iran

2 Department of Physical Education, Laboratory of Morphoquantitative Studies and Immunohistochemistry, Sao Judas Tadeu University, 546 - Mooca Unit, P.O box 03166-000, Sao Paulo, SP, Brazil 